\title{
Prolonged Effects of Repeated Social Defeat Stress on mRNA Expression and Function of $\mu$-Opioid Receptors in the Ventral Tegmental Area of Rats
}

\author{
Ella M Nikulina*,', Klaus A Miczek ${ }^{1,2,3}$ and Ronald P Hammer Jr ${ }^{1,3}$ \\ 'Department of Psychiatry, Tufts University, Boston, MA, USA; ${ }^{2}$ Department of Psychology, Tufts University, Medford, MA, USA; ${ }^{3}$ Department of \\ Pharmacology and Experimental Therapeutics, Tufts University, Boston, MA, USA
}

\begin{abstract}
Social defeat stress alters the activity of mesocorticolimbic dopamine projections from the ventral tegmental area (VTA), a process that has been implicated in the development of sensitization and drug-seeking behavior. We showed previously that acute brief social defeat stress increased short-term expression of $\mu$-opioid receptor mRNA in the VTA. The present study assessed the presence and functional significance of $\mu$-opioid receptor mRNA expression I week after the last episode of social defeat stress. Social defeat stress was induced in intruder rats during short confrontations with an aggressive resident rat, and subsequent exposures behind a protective screen once a day for 5 days. Regional $\mu$-receptor mRNA levels were assessed by in situ hybridization histochemistry, and the amount of mRNA labeling was measured in the VTA and the substantia nigra (SN). Expression of $\mu$-opioid receptor mRNA was significantly higher in defeated rats relative to handled control animals in the VTA, but not in the SN. In an additional group of rats, bilateral local intra-VTA injection of the selective $\mu$-opioid receptor agonist DAMGO ( $1.0 \mu \mathrm{g}$ per side) was performed 7-10 days after the last defeat stress or handling control procedure. Baseline motor activity did not differ between control and stressed rats. Intra-VTA DAMGO significantly increased locomotor activity in stressed rats compared to handled control rats. These results suggest that repeated social stress upregulates VTA $\mu$-opioid receptors and can produce locomotor activation via stimulation of these receptors. This locomotor effect is probably the consequence of enhanced disinhibition of mesolimbic dopamine neurons.
\end{abstract}

Neuropsychopharmacology (2005) 30, 1096-I I03, advance online publication, 19 January 2005; doi: I0.1038/sj.npp. 1300658

Keywords: stress; $\mu$ receptor; opioid; ventral tegmental area; DAMGO; locomotion

\section{INTRODUCTION}

Opioid peptides are mediators of different kinds of stress responses (Drolet et al, 2001). Opioid neurons and their receptors are present in stress-related areas of the telencephalon (eg frontal cortex, amygdala, septum, bed nucleus of stria terminalis) and brain stem (Watson et al, 1982; Mansour et al, 1995). The behavioral and neurochemical effects of opioids differ according to the type of opioid receptors with which they interact (Akil et al, 1997; Spanagel et al, 1992). $\mu$-Opioid receptor binding is increased after immobilization stress, water deprivation, or foot-shock in several regions of the limbic system (Zeman et al, 1988; Stein et al, 1992). Neurons containing

*Correspondence: Dr EM Nikulina, Department of Psychiatry, Box 1007, Tufts-New England Medical Center, 750 Washington St, Boston, MA 021।I, USA, Tel: + 617636 8949, Fax: + 6176368934 ,

E-mail: ella.nikulina@tufts.edu

Received 28 July 2004; revised 23 November 2004; accepted 24 November 2004

Online publication: 29 November 2004 at http://www.acnp.org/citations/ NPPI I 2904040336/default.pdf opioid receptors are moderately dense in the ventral tegmental area (VTA), a region that supplies mesolimbic projections to the ventral striatum. $\mu$-Opioid receptors are expressed by GABAergic neurons in the VTA, which are hyperpolarized by $\mu$-receptor stimulation, thereby reducing inhibitory GABA-mediated synaptic input to dopaminergic neurons (Johnson and North, 1992). Thus, alteration of $\mu$ opioid receptor function in the VTA could have a profound effect on dopamine-mediated behaviors. One functional effect of local VTA $\mu$-opioid receptor stimulation is the dose-dependent enhancement of locomotor activity (Stinus et al, 1980; Vezina et al, 1987).

Endogenous opioid systems, particularly those involving $\mu$-opioid receptors, mediate many aspects of defensive and submissive behaviors in rodents (Miczek et al, 1982; Rodgers and Randall, 1985). Midbrain opioid mechanisms participate in the regulation of affective and ultrasonic vocalization, which are components of submissive responses during social defeat stress (Herman and Panksepp, 1981; Vivian and Miczek, 1999). Social defeat stress selectively alters dopamine efflux in the mesocorticolimbic dopamine projections (Tidey and Miczek, 1996), which has 
been implicated in the development of sensitization and drug-seeking behavior (Robinson and Berridge, 1993; Vanderschuren and Kalivas, 2000). The increased response to repeated intermittent psychostimulant administration or behavioral sensitization is thought to reflect plastic changes in neurocircuits that determine the hypersensitivity to psychostimulant challenge (Robinson and Becker, 1986). The VTA is a critical area for the induction of drug-induced sensitization (Cador et al, 1995). Acute social defeat stress in rats induces upregulation of $\mu$-opioid receptor mRNA expression in the VTA, which is exemplified by an increased number of labeled cells and increased labeling in each cell (Nikulina et al, 1999). This increased $\mu$-opioid receptor mRNA expression occurs rapidly and lasts at least $6 \mathrm{~h}$. We hypothesized that repeated social defeat stress would induce $\mu$-opioid receptor mRNA expression in the VTA for a much longer period, and that this long-lasting change could be relevant to stress-induced changes in dopamine-dependent behavior.

The present study compared the expression of $\mu$-opioid receptor mRNA in VTA and substantia nigra (SN) 1 week after termination of repeated social defeat stress or handling. The functional significance of $\mu$-opioid receptors in the VTA was measured in parallel. In order to test the hypothesis that upregulated $\mu$-opioid receptors in the VTA are important for the induction of stress-induced locomotor sensitization, a selective $\mu$-opioid receptor agonist, [D$\mathrm{Ala}^{2}, \mathrm{~N}-\mathrm{MePhe}^{4}, \mathrm{Gly}^{-\mathrm{ol}^{5}}$ ] enkephalin (DAMGO), was applied locally to stimulate VTA $\mu$-opioid receptors in rats after repeated social defeat stress or handling procedures.

\section{MATERIALS AND METHODS}

\section{Subjects}

The subjects were male Sprague-Dawley rats (Charles River Laboratories, Wilmington, MA, USA), weighing 200-250 g upon arrival. They were housed individually in standard plastic cages $(24 \times 45 \times 20 \mathrm{~cm})$ under a reverse 12 -h lightdark cycle (lights off at 0900 hours) with unlimited access to food and water. Stimulus male Long-Evans rats, termed 'residents,' were pair-housed with females. Each resident was characterized by consistent display of aggressive reactions toward an intruder rat (Miczek, 1979). Resident pairs were housed in large cages $(37 \times 50 \times 20 \mathrm{~cm})$. All experimental procedures were approved by the Tufts-New England Medical Center Institutional Animal Care and Use Committee, in accord with the Guide for the Care and Use of Laboratory Animals (National Research Council, 2003). In addition, all efforts were made to minimize animal suffering and to use the minimal necessary number of animals.

\section{Experimental Design}

General procedure. All experimental animals were allowed to adapt to the laboratory conditions for at least 1 week after arrival. Animals were randomly assigned to either an experimental 'social defeat stress' group or to a nonstressed control group. Experimental rats were exposed to repeated social defeat stress daily for 5 days, and control rats were handled at the same time but not exposed to residents. The female rat was removed from the resident's cage prior to social stress exposure. Brain tissue for in situ hybridization histochemistry (ISHH) was collected 7 days after the last social defeat stress or handling procedure. Alternatively, behavioral tests for sensitivity to intra-VTA DAMGO injections were carried out 7-10 days after these procedures.

Behavioral procedures. Social defeat stress consisted of a short aggressive confrontation between an aggressive resident rat and an experimental intruder rat, with subsequent exposure behind a protective screen to threats of the resident rat. After the experimental rat was placed into the resident's cage, the resident attacked the intruder, which exhibited defeat behavior. Defeat was identified as the display of a submissive supine posture for at least $4 \mathrm{~s}$, which usually occurred following 4-5 bites within a maximum of $5 \mathrm{~min}$. As soon as the experimental intruder rat displayed submissive postures, the intruder was covered with a protective wire mesh cage and remained within the resident's cage for further exposure to threats by the residents for an additional $25 \mathrm{~min}$ behind a protective screen. Rats were exposed to social defeat stress once daily on each of 5 consecutive days.

Locomotor activity. Motor activity of animals was measured in two different ways: using a tracking system, expressed as total distance traveled during experiment and by recording behavior on videotape for subsequent detailed analysis.

Total motor activity of animals was measured using a tracking system (Polytrack; San Diego Instruments, CA, USA) during a $50 \mathrm{~min}$ period, starting immediately after intra-VTA infusion. The PolyTrack system consists of a CCD video camera mounted above a platform on which two cages are placed for behavioral monitoring. The camera is interfaced to a computer, which records activity data. The system was used to determine the exact location within the cage of the rat's neck region, which was marked with a spot of permanent hair coloring. A custom software program was used to distinguish and quantify smaller movements that occur during stereotypy. To avoid measurement of nonspecific movement (eg due to respiration in a stationary animal), the threshold for movement detection was set to a radius of $2 \mathrm{~cm}$.

Behavior of subjects was also recorded on videotape using a low-lux video camera and a standard videocassette recorder during $5 \mathrm{~min}$ intervals starting $15 \mathrm{~min}$ before (baseline of motor activity), and then $5 \mathrm{~min}$ (5-10 min after infusion) and $25 \mathrm{~min}(25-30 \mathrm{~min})$ after intra-VTA infusion. These postinfusion time points represent the initial behavioral response and subsequent behavioral effect of infusion. Each video recording was analyzed by a trained observer, who was unaware of the treatment condition, using a customized keyboard and commercial software (Observer Video Pro, Noldus) to detect behavioral parameters such as frequency of walking, rearing, and grooming.

\section{Experiment 1: $\mu$-Opioid Receptor mRNA Expression in Dopaminergic Brain Regions}

For ISHH, rats ( $n=4$ for handled control and $n=5$ for stressed groups) were anesthetized with sodium pentobar- 
bital $(100 \mathrm{mg} / \mathrm{kg}$, i.p). After the animals were decapitated, the brains were removed and rapidly frozen in isopentane, then wrapped in parafilm and aluminum foil. Brains were stored at $-80^{\circ} \mathrm{C}$ prior to sectioning in a cryostat. Sections $(20 \mu \mathrm{m})$ containing VTA and SN were taken from the midbrain at a level -4.9 to $-5.3 \mathrm{~mm}$ from bregma (Paxinos and Watson 1986), then mounted on glass slides (Superfrost/Plus, Fisher) and stored at $-30^{\circ} \mathrm{C}$ before processing. ISHH was performed using a $\left[{ }^{33} \mathrm{P}\right] \mathrm{UTP}$-labeled cRNA probe of 450 bases corresponding to transmembrane coding regions III and IV (generously provided by $\mathrm{Dr} \mathrm{H}$ Akil). The cRNA was synthesized by standard in vitro transcription using $0.2 \mu \mathrm{g}$ linearized plasmid DNA, $25 \mu \mathrm{M}\left[{ }^{33} \mathrm{P}\right] \mathrm{UTP}$, excess GTP, CTP, and ATP $(500 \mu \mathrm{M}$ each $), 2 \mathrm{mM}$ spermidine, $10 \mathrm{mM}$ DTT, $4 \mathrm{U} / \mu \mathrm{l}$ RNAsin, and $5 \mathrm{U}$ RNA polymerase (T7, Promega), incubated for $2 \mathrm{~h}$ at $37^{\circ} \mathrm{C}$. The radiolabeled cRNA was purified by phenol/chloroform/isoamyl alcohol extraction and a Quick Spin column (Boehringer Mannheim). The probe was then diluted with hybridization buffer, and hybridization was accomplished at $55^{\circ} \mathrm{C}$ for $16 \mathrm{~h}$ in a humidified chamber. Afterwards, sections were treated with RNAse A ( $30 \mathrm{~min}$ at $\left.37^{\circ} \mathrm{C}\right)$, followed by a series of high stringency washes $(15 \mathrm{~min}$ at room temperature in $1 \times \mathrm{SSC}$; twice for $30 \mathrm{~min}$ at $67^{\circ} \mathrm{C}$ in $0.1 \times \mathrm{SSC}$, followed by $10 \mathrm{~min}$ at room temperature in $0.1 \times \mathrm{SSC}$ ). Sections were then rapidly dehydrated in graded alcohols and air-dried. The slides were exposed first to X-ray film (Biomax MR, Kodak, Rochester, NY, USA) for 5 days. They were then dipped in liquid photograph emulsion (NTB-2, Kodak, Rochester, NY, USA) and exposed for 3 weeks in lightproof boxes with desiccant at $-35^{\circ} \mathrm{C}$. Following development, the slides were stained with thionin, and coverslipped.

Image analysis. The expression of $\mu$-opioid receptor mRNA was assessed using both quantitative regional X-ray film and microscopic analyses. Regional autoradiographs were assessed in defined brain regions by digitization using a CCD camera connected to a Macintosh computer. Brain regions were identified using a rat stereotaxic atlas (Paxinos and Watson 1986). Autoradiographic measurements were collected bilaterally from three adjacent VTA sections. SN pars compacta and SN pars reticulata exhibited low signal on X-ray film in experimental and control groups, and measurements were made in three adjacent sections by selecting the entire SN without division into subregions. Quantification of regional optical density was performed using public domain image-analysis software (NIH-IMAGE; developed by Wayne Rasband and available on the Internet at http://rsb.info.nih.gov/nih-image/) using calibrated radiostandards (ARC-146; American Radiolabeled Chemicals, St Louis, MO, USA) to generate a calibration curve in $\mathrm{cpm} / \mathrm{mg}$.

For microscopic analysis, the number of labeled neurons was determined within $280 \mu \mathrm{m}^{2}$ viewing fields from both sides of the VTA and the SN. Quantification of silver grains in labeled neurons was accomplished using NIH Image grain-counting software (developed by Wayne Rasband, NIMH; available on the Internet at http://rsb.info.nih.gov/ nih-image/). Labeling was also measured in adjacent cellsized regions that did not contain Nissl staining, which represented background. Neurons were considered to be labeled if the number of autoradiographic grains was at least three times higher than background. The density of labeling was normalized as a labeling ratio calculated by dividing the number of grains per cell by the number of background grains (Hammer and Cooke, 1996). The labeling ratio was determined in 8-10 neurons in each of at least three adjacent sections from each region of interest in each rat. These data were averaged to determine mean values for each animal.

\section{Experiment 2. Intra-VTA Infusion and Locomotor Activity}

Surgery. At 1 week before the start of the stress procedure, rats were implanted with bilateral guide cannulae directed at the VTA under general anesthesia with isoflurane. These 23 gauge guide cannulae (Plastics One; Roanoke, VA, USA), positioned $2 \mathrm{~mm}$ above their final destination, were directed towards the stereotaxic coordinates $\mathrm{AP}=-5.0 \mathrm{~mm}$; $\mathrm{ML}= \pm 0.23 \mathrm{~mm}$ from midline; $\mathrm{DV}=-8.2 \mathrm{~mm}$ from the skull surface, angle $10^{\circ}$ (Paxinos and Watson, 1986). The cannulae were permanently fixed to the skull with microscrews and dental cement, and removable stainless steel dummy cannulae of the same length were inserted into the guide cannulae to prevent clogging.

The animals were subjected to social defeat stress $(n=10)$ or to the handling control $(n=6)$ procedures daily for 5 consecutive days as described above. Local intra-VTA infusions and measurement of locomotor activity were performed during the dark phase of the light cycle between 1200 and 1600 hours. Rats were adapted to head-mount manipulation for at least 3 days prior to the infusion procedure. They were also acclimated to the testing room and to the clean, empty testing chamber three times prior to the experiment. At 1 day before the first intra-VTA infusion, the dummy cannulae were replaced with bilateral 31 gauge infusion cannulae extending $2 \mathrm{~mm}$ beyond the guide cannules, and baseline locomotor behavior was assessed. Each rat then received bilateral infusions of saline or DAMGO into the VTA using a counterbalanced design. DAMGO (Multiple Peptide Systems, San Diego, CA, USA) infusion utilized $1.0 \mu \mathrm{g}(2 \mathrm{nM})$ in $0.5 \mu \mathrm{l}$ of $0.9 \%$ sterile saline vehicle on each side. Intra-VTA infusions were performed starting 7-9 days after the last defeat stress or handling control procedure. This dose of DAMGO was chosen as the median effective dose known to enhance locomotion (Meyer and Meyer, 1993; Kamei et al, 1995). Simultaneous bilateral infusions were delivered over 3 min using an infusion pump (Instech, KD Scientific, USA) in awake, unrestrained rats. The infusion cannulae remained in place for an additional 2 min after the infusion to prevent back flow, and behavior was measured immediately after removal of the infusion cannulas. The second infusion was made 2 days later.

Histology. At the end of the experiment, the location of the cannula track and tip was confirmed by histological assessment (Figure 1). Rats were deeply anesthetized with sodium pentobarbital $(100 \mathrm{mg} / \mathrm{kg}$, i.p.); brains were removed after decapitation, then rapidly frozen in isopentane, and stored at $-80^{\circ} \mathrm{C}$ prior to sectioning. Coronal $20 \mu \mathrm{m}$ sections of the VTA region were obtained, mounted on slides and stained with thionin. Rats with cannula place- 


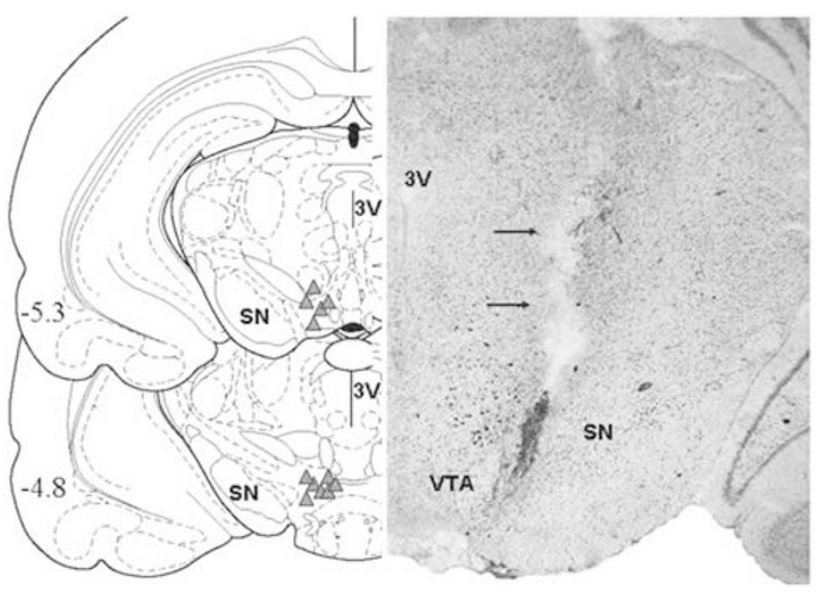

Figure I Left: Schematic presentation of cannula placements in the VTA (Paxinos and Watson, 1986). Right: Photomicrograph of a typical cannula placement in the VTA in a Nissl-stained section.

ments outside the VTA were excluded from the behavioral analysis.

\section{Data Analysis}

The results of $\mu$-opioid receptor mRNA expression were analyzed using $t$-tests that compared data from the stressed group to the handled control group. Behavioral data were analyzed by two-way ANOVA with two between-subject factors (environment and drug treatment) followed by post hoc comparisons using the Bonferroni $t$-test, when applicable (SigmaStat, SPSS Inc., San Rafael, CA, USA).

\section{RESULTS}

\section{$\mu$-Opioid Receptor mRNA Expression is Upregulated after Repeated Social Defeat Stress}

Analysis of film autoradiograph revealed that $\mu$-opioid receptor mRNA exhibited low constitutive expression in the VTA of control rats, in agreement with previously described low basal $\mu$-opioid receptor mRNA expression in rat VTA (Mansour et al, 1994; Delfs et al, 1994). The autoradigraphic density of $\mu$-opioid receptor mRNA labeling significantly increased after repeated social defeat stress. The expression of $\mu$-opioid receptor mRNA in the VTA was twice as high in stressed rats as in handled control animals $(t=2.95, \mathrm{df}=7$, $p=0.042$; Figures 2 and 4a). Examination of Nissl-stained sections corresponding to film autoradiographs revealed that the most intense expression of $\mu$-opioid receptor mRNA in previously stressed rats was present in regions of the VTA dorsolateral to the interpeduncular nucleus.

A detailed analysis of the distribution of $\mu$-opioid receptor mRNA in the VTA was performed in sections processed for emulsion autoradiography, which allows for detection of labeling at the single cell level. $\mu$-Opioid receptor mRNA labeling in Nissl-stained neurons located in the VTA showed clear differences between handled and stressed rats (Figure 3). Silver particles indicating the presence of $\mu$-opioid receptor mRNA were distributed more densely in labeled neurons of previously stressed rats than
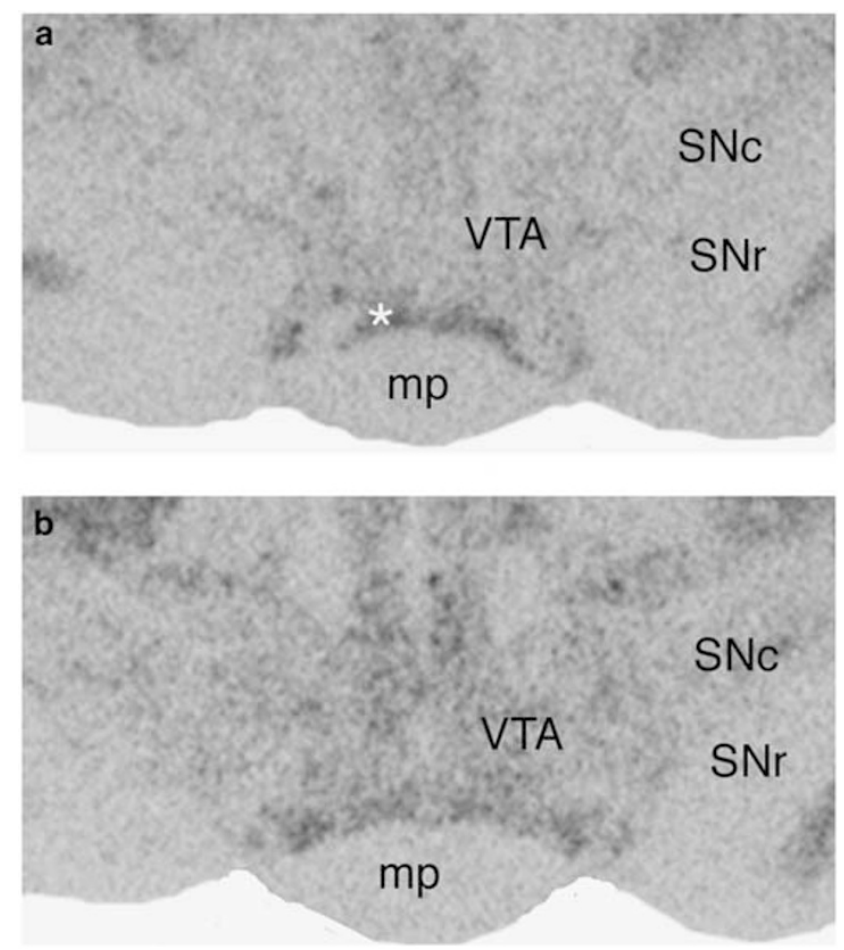

Figure 2 Representative film autoradiographs showing the effect of repeated social defeat stress on $\mu$-opioid receptor mRNA expression in handled control (a) and stressed (b) rats in the VTA and SN 7 days after stress exposure. Note higher $\mu$-opioid receptor mRNA expression in the VTA of the stressed rat shown in (b), but not in the SN. Abbreviations: $\mathrm{SNc}$ - substantia nigra, pars compacta; $\mathrm{SNr}$ - substantia nigra, pars reticulate; $\mathrm{mp}$-mammilary peduncle. ${ }^{*}$-rostral rim of interpeduncular nucleus.

of handled rats. Quantitative analysis of the number of cells expressing $\mu$-opioid receptor mRNA indicated a two-fold increase in the number of labeled cells after repeated social defeat exposures $(t=3.53, \mathrm{df}=7, p=0.010$; Figure $4 \mathrm{~b})$. Similarly, the labeling ratios, which indicate the number of grains per cell relative to background labeling, increased significantly in stressed animals, being more than $60 \%$ higher than in handled animals (Figure $4 \mathrm{c} ; t=2.64, \mathrm{df}=7$, $p<0.05$; Figure $4 c$ ).

In contrast, repeated social defeat stress exposure had no effect on $\mu$-opioid receptor mRNA expression in the SN. Xray film autoradiography revealed a low level of $\mu$-opioid receptor mRNA expression in $\mathrm{SN}$, with no difference between handled and previously stressed animals. The number of labeled cells within the SN did not differ between the control and experimental groups (Figures 2 and $4 \mathrm{a}, \mathrm{b}$ ).

\section{Intra-VTA Injections of DAMGO Induce Greater Locomotor Activity in Rats after Repeated Social Defeat Stress}

It was observed that the baseline level of locomotion measured by the tracking system did not differ significantly between social defeat stressed and handled control rats $(42.16 \pm 7.73$ units in stressed rats $v s 35.59 \pm 6.62$ units in handled control rats), nor did locomotor activity differ between handled and stressed rats after intra-VTA vehicle infusion. Furthermore, the response to vehicle infusion did 

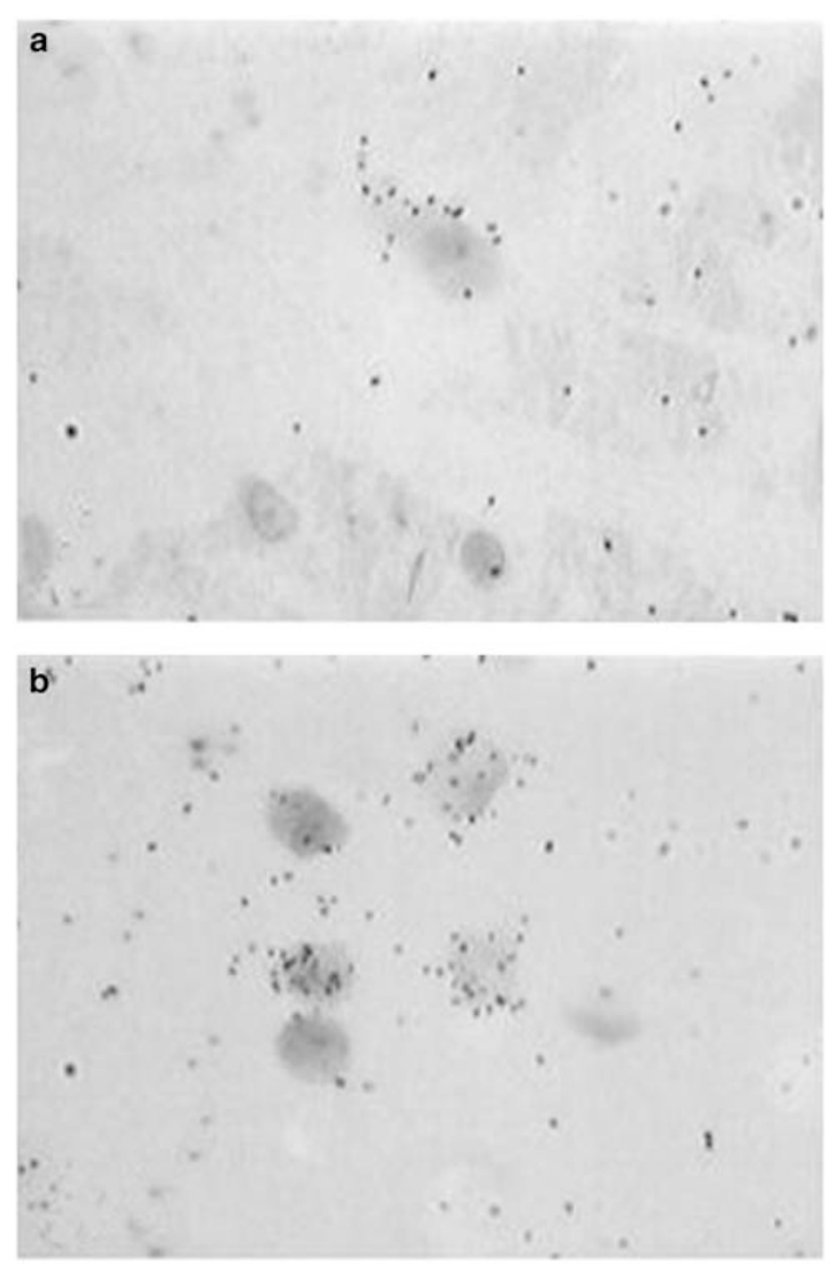

Figure 3 Bright-field light microphotographs showing exposed silver grains denoting $\mu$-opioid receptor mRNA labeling atop Nissl-stained neurons located in the VTA of a handled control rat (a), and a rat exposed to repeated social defeat stress (b). Note the increased number of labeled neurons and increased amount of silver grains (denoting $\mu$-opioid receptor mRNA) in the VTA of the rat subjected to social defeat stress. Original magnification $-\times 400$. not differ, regardless of whether vehicle was injected as the first or second compound. In contrast, intra-VTA DAMGO infusion significantly increased total locomotor activity in both handled and stressed groups $\left(F_{1,36}=24.78 ; p<0.001\right.$; Figure 5a). Furthermore, the effect of social defeat stress was significant $\left(\mathrm{F}_{1,36}=10.41 ; p=0.003\right)$, and the DAMGO $\times$ defeat interaction approached significance $\left(\mathrm{F}_{1,36}=3.96\right.$; $p=0.054$ ). Finally, locomotor activity of stressed rats was higher after DAMGO treatment than in handled control rats (Bonferroni $t$-test $=3.69, p<0.001$ ). Locomotor activity had returned to baseline levels by the end of the $50 \mathrm{~min}$ test, indicating that DAMGO effects had subsided by the end of the experiment.

Detailed analysis of behavioral parameters after intraVTA DAMGO injection revealed a significant effect on the frequency of walking. The average frequency of walking assessed prior to DAMGO infusion and during the first recorded $5 \mathrm{~min}$ interval (5-10 $\mathrm{min}$ after infusion) was similar in handled and defeated rats, but walking activity was significantly higher during the interval recorded 2530 min after DAMGO infusion in stressed rats $\left(\mathrm{F}_{1,32}=7.38\right.$; $p=0.01$; Figure $5 \mathrm{~b}$ ). After DAMGO infusion, socially stressed rats exhibited more frequent walking than did handled control rats (Bonferroni $t$-test $=2.48, p=0.019$ ).

Finally, the frequency of rearing was similar in handled and stressed rats during baseline tests $(11.0 \pm 2.0$ in control vs $10.3 \pm 3.0$ in experimental rats). At $25 \mathrm{~min}$ after DAMGO infusion, stressed rats tended to rear more, but differences between the groups did not reach significance $(5.5 \pm 1.8$ in control $v s 16.2 \pm 7.5$ in experimental rats; $p>0.05$ ). Grooming behaviors were unaffected by intra-VTA DAMGO administration. The frequency of grooming $25 \mathrm{~min}$ after DAMGO infusion was unaltered $(0.5 \pm 0.3$ in stressed rats $v s$ $0.5 \pm 0.3$ in handled rats).

\section{DISCUSSION}

The present study is the first to show that repeated exposure to social defeat stress upregulates $\mu$-opioid receptor mRNA
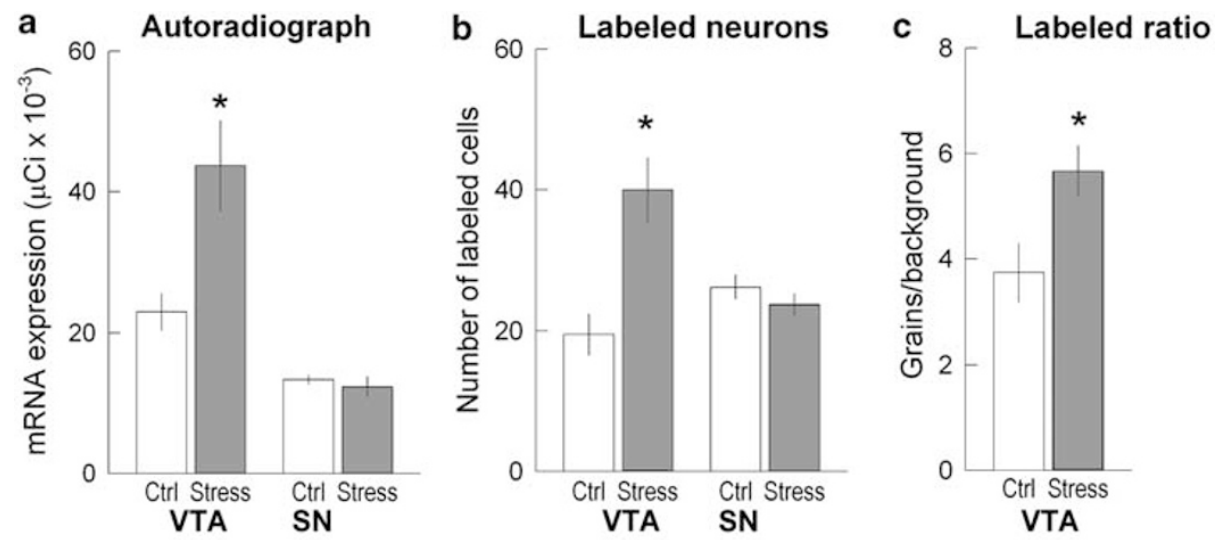

Figure 4 Stress-induced increase of $\mu$-opioid receptor mRNA in the VTA, but not in the SN. (a) optical density in film autoradiographs expressed as $\mu$ Ci/g of calibrated radiostandard; (b) the number of labeled neurons in the VTA and SN; (c) labeling ratio in the VTA after repeated social defeat stress. Ctrl — control handled group; Stress — social defeat stress group. Values represent mean and standard error. ${ }^{*} p<0.05$. 


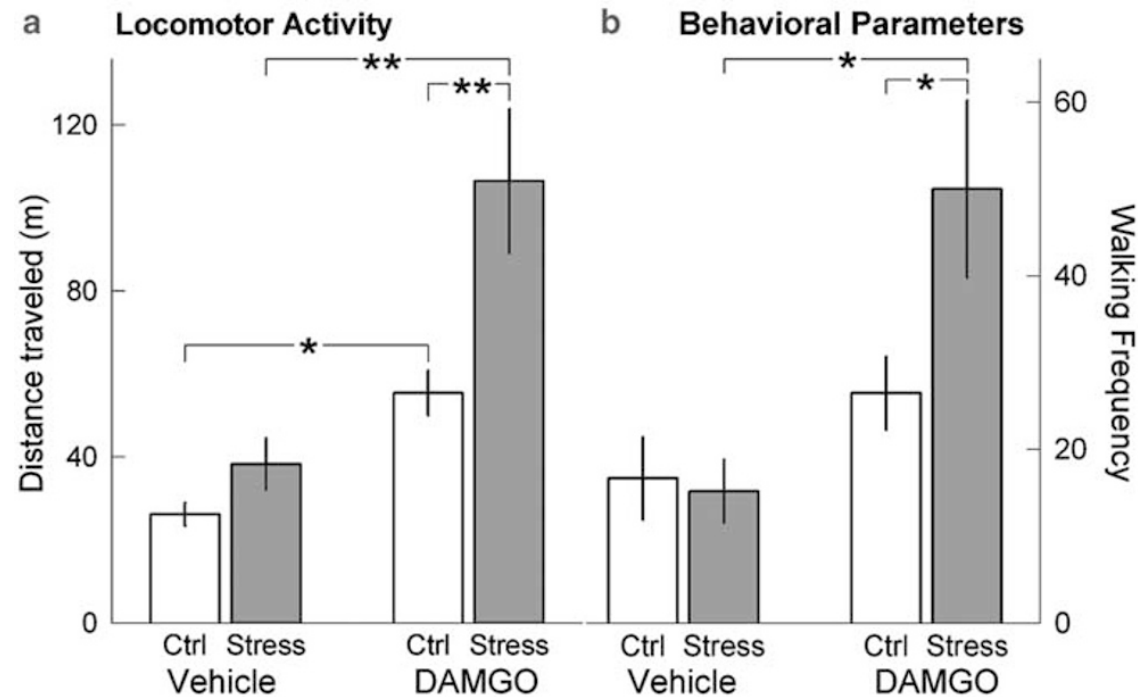

Figure 5 Induction of locomotor activity after local intra-VTA infusion of saline or DAMGO following repeated handling or social defeat stress exposure. (a) Total locomotor activity of rats following local intra-VTA injection of vehicle (saline) and DAMGO 7 days after social defeat stress exposure. (b) Frequency of locomotor activity was measured during 5 min epochs either before DAMGO infusion at baseline (left) or 25 min after DAMGO infusion (right). Ctrl — control handled group; Stress — social defeat stress group. Exposure to repeated social defeat stress significantly increased the effect of intraVTA DAMGO infusion on locomotor activity. Values represent mean and standard error $(* p<0.05$; $* * p<0.00$ I)

in the VTA 1 week after the last stress exposure. Furthermore, the results suggest that this elevated expression of $\mu$-opioid receptor mRNA is translated into functional receptor proteins in the VTA. Thus, local stimulation of VTA $\mu$-opioid receptors by DAMGO causes greater locomotor activity after social defeat stress exposure than after handling. This selective regional alteration confers a molecular substrate that may underlie the impact of social defeat stress on the development of drug sensitization or other mesolimbic dopamine-related behaviors.

$\mu$-Opioid receptors within the VTA are mainly localized in nondopamine interneurons containing GABA (Johnson and North, 1992; Garzon and Pickel, 2001), many of which make synaptic contact with dopamine neurons. However, $\mu$ opioid immunolabeling can also be found on dopaminergic dendrites in the VTA (Garzon and Pickel, 2001), which might account for chronic $\mu$-opioid-induced increases of tyrosine hydroxylase (Self et al, 1995). $\mu$-Opioid agonists indirectly stimulate dopaminergic VTA neurons; $\mu$-opioid agonists inhibit GABA interneurons, which in turn lead to the disinhibition of dopamine neurons (Johnson and North, 1992; Cameron et al, 1997). Our results suggest that stressinduced enhancement of $\mu$-opioid activity in the VTA also affects dopaminergic neurotransmission indirectly; greater locomotor response to local DAMGO infusion is probably due to increased dopaminergic transmission in neurons that innervate the NAc. Another possibility is that VTA GABAergic neurons that receive opioid input directly innervate the NAc, in which case the functional activity in the NAc would likely increase upon VTA DAMGO infusion due to opioid inhibition of GABAergic input. At least onethird of VTA neurons projecting to the NAc contain GABA (Van Bockstaele and Pickel, 1995), and this GABA-containing pathway might represent a substrate for influence on NAc neuronal activity (Carr and Sesack, 2000). We recently observed that Fos-like immunoreactivity was increased in
VTA neurons 1 week after repeated social defeat stress exposure (Nikulina et al, 2004). Increased Fos expression might influence $\mu$-opioid receptor expression, since the $\mu$ opioid promoter region contains a consensus AP-1 site (Min et al, 1994), which is activated by immediate early genes (Morgan and Curran, 1991). However, the type of cells that expressed Fos in the VTA and the proportion of these cells that are GABAergic remains unknown.

The involvement of VTA $\mu$-opioid activity in stress responses has been reported previously following footshock or restraint stress exposure. Footshock or immobilization rapidly enhances the release of the endogenous $\mu$-agonist, enkephalin, in the lateral VTA (Kalivas and Abhold, 1987) and acute restraint stress increases $\mu$-opioid receptor mRNA expression in midbrain homogenates (Yamamoto et al 2003). Social defeat stress, as used herein, is a naturalistic as an ethological stimulus with enduring behavioral and physiological consequences (Tornatzky and Miczek, 1993; Miczek et al, 2004). This might explain why VTA $\mu$-opioid receptor mRNA expression was rapidly induced (Nikulina et al, 1999) and remained elevated 1 week after the termination of repeated social stress, whereas three repeated presentations of restraint stress produced habituation to $\mu$-opioid receptor mRNA induction in the midbrain (Yamamoto et al, 2003).

The presence of increased VTA $\mu$-opioid receptor mRNA after repeated social defeat stress suggests the involvement of the VTA opioids in the behavioral consequences of stress. Intra-VTA infusion of the $\mu$-opioid agonist DAMGO induced greater locomotion in rats with prior exposure to repeated social defeat stress, reflecting the increased effect of $\mu$-opioid receptor stimulation in the VTA of stressed animals. Stimulation of VTA $\mu$-opioid receptors is known to cause locomotor activation (Broekkamp et al, 1979; Stinus et al, 1980; Kalivas et al, 1985), presumably via increased dopamine concentration in the NAc (Kalivas, 1985; Kalivas and Duffy, 1988; Spanagel et al, 1992). Interactions between 
opioid peptides and the dopamine system in behavioral responses to stressors have been demonstrated previously, suggesting that endogenous opioid peptides are released specifically during exposure to environmental stimulation. For example, infusion of the antiopioid peptide, neuropeptide FF, into the VTA reduced locomotor response to novelty, whereas an inhibitor of enkephalin degradation strongly increased novelty-induced locomotion (Cador et al, 2002). Moreover, it has been shown that chronic cocaine treatment increases $\mu$-opioid receptor density in dopaminergic projection regions both in rats (Hammer, 1989; Unterwald et al, 1992) and human cocaine addicts (Zubieta et al, 1996), indicating that dopaminergic and opioid systems have reciprocal interaction with regard to their reinforcing effects. The respective neurobiological substrates for the induction and the expression of behavioral sensitization, which may represent a key processes underlying addiction (Robinson and Berridge, 1993), have been dissociated neuroanatomically. The VTA appears to be the critical site for the induction of sensitization, while the NAc represents the site regulating expression of behavioral sensitization (Vezina et al, 1987; Perugini and Vezina, 1994; Cador et al, 1995). Recently, it was shown that prolonged amphetamine-induced behavioral sensitization is accompanied by elevated $\mu$-opioid, but not $\delta$-opioid, receptor mRNA expression in the VTA (Magendzo and Bustos, 2003). This observation is consistent with our suggestion that increased VTA $\mu$-opioid receptor mRNA expression predisposes animals to a sensitized response to psychostimulant challenge (Covington and Miczek 2001; Nikulina et al, 2004). After intermittent social defeat stress exposure, rats show long-lasting cross-sensitization to amphetamine challenge, which is evident up to 2 months later. Elevated VTA $\mu$-opioid activity after repeated social defeat stress might be one of the mechanisms underlying such prolonged cross-sensitization to psychostimulants.

In summary, the major finding of the present experiments is that repeated exposure to social defeat stress causes persistent induction of functional $\mu$-opioid receptors in the VTA. Such enhanced $\mu$-opioid receptor function in the VTA is proposed to increase the vulnerability of individuals to the subsequent exposure to psychomotor stimulants.

\section{ACKNOWLEDGEMENTS}

This research was supported by USPHS awards DA14327 (EMN), DA02632 (KAM), and MH066954 (RPH). We thank Mr J Thomas Sopko for assistance in the statistical analyses of the data and preparation of the manuscript.

\section{REFERENCES}

Akil H, Meng F, Devine DP, Watson SJ (1997). Molecular and neuroanatomical properties of the endogenous opioid system: implications for treatment of opiate addiction. Semin Neurosci 9: 70-83.

Broekkamp CL, Phillips AG, Cools AR (1979). Stimulant effects of enkephalin microinjection into the dopaminergic A10 area. Nature 278: 560-562.

Cador M, Bjijou Y, Stinus L (1995). Evidence of a complete independence of the neurobiological substrates for the induction and expression of behavioral sensitization to amphetamine. Neuroscience 65: 385-395.

Cador M, Marco N, Stinus L, Simonnet G (2002). Interaction between neuropeptide FF and opioids in the ventral tegmental area in the behavioral response to novelty. Neuroscience 110: 309-318.

Cameron DL, Wessendorf MW, Williams JT (1997). A subset of ventral tegmental area neurons is inhibited by dopamine, 5-hydroxytryptamine and opioids. Neuroscience 77: 155-166.

Carr DB, Sesack SR (2000). Projections from the rat prefrontal cortex to the ventral tegmental area: target specificity in the synaptic associations with mesoaccumbens and mesocortical neurons. J Neurosci 20: 3864-3873.

Covington III HE, Miczek KA (2001). Repeated social-defeat stress, cocaine or morphine. Effects on behavioral sensitization and intravenous cocaine self-administration 'binges'. Psychopharmacology 158: 388-398.

Delfs JM, Kong H, Mestek A, Chen Y, Yu L, Reisine T et al (1994). Expression of mu opioid receptor mRNA in rat brain: an in situ hybridization study at the single cell level. J Comp Neurol 345: 46-68.

Drolet G, Dumont EC, Gosselin I, Kinkead R, Laforest S, Trottier JF (2001). Role of endogenous opioid system in the regulation of the stress response. Prog Neuropsychopharmacol Biol Psychiatry 25: 729-741.

Garzon M, Pickel VM (2001). Plasmalemmal mu-opioid receptor distribution mainly in nondopaminergic neurons in the rat ventral tegmental area. Synapse 41: 311-328.

Hammer Jr RP (1989). Cocaine alters opiate receptor binding in critical brain reward regions. Synapse 3: 55-60.

Hammer Jr RP, Cooke ES (1996). Sensitization of neuronal response to cocaine during withdrawal following chronic treatment. NeuroReport 7: 2041-2045.

Herman BH, Panksepp J (1981). Ascending endorphin inhibition of distress vocalization. Science 211: 1060-1062.

Johnson SW, North RA (1992). Opioids excite dopamine neurons by hyperpolarization of local interneurons. J Neurosci 12: 483-488.

Kalivas PW (1985). Sensitization to repeated enkephalin administration into the ventral tegmental area of the rat. II. Involvement of the mesolimbic dopamine system. J Pharmacol Exp Therap 235: 544-550.

Kalivas PW, Abhold R (1987). Enkephalin release into the ventral tegmental area in response to stress: modulation of mesocorticolimbic dopamine. Brain Res 414: 339-348.

Kalivas PW, Duffy P (1988). Effects of daily cocaine and morphine treatment on somatodendritic and terminal field dopamine release. J Neurochem 50: 1498-1504.

Kalivas PW, Taylor S, Miller JS (1985). Sensitization to repeated enkephalin administration into the ventral tegmental area of the rat. I. Behavioral characterization. J Pharmacol Exp Ther 235: 537-543.

Kamei J, Ohsawa M, Saitoh A, Iwamoto Y, Suzuki T, Misawa M et al (1995. Modification of mu-opioid agonist-induced locomotor activity and development of morphine dependence by diabetes. J Pharmacol Exp Ther 274: 700-706.

Magendzo K, Bustos G (2003). Expression of amphetamineinduced behavioral sensitization after short- and long-term withdrawal periods: participation of mu- and delta-opioid receptors. Neuropsychopharmacology 28: 468-477.

Mansour A, Fox CA, Akil H, Watson SJ (1995). Opioid-receptor mRNA expression in the rat CNS: anatomical and functional implications. Trends Neurosci 18: 22-29.

Mansour A, Fox CA, Burke S, Meng F, Thompson RC, Akil H et al (1994). Mu, delta, and kappa opioid receptor mRNA expression in the rat CNS: an in situ hybridization study. J Comp Neurol 350: $412-438$. 
Meyer ME, Meyer ME (1993). Behavioral effects of opioid peptide agonists DAMGO, DPDPE, and DAKLI on locomotor activities. Pharmacol Biochem Behav 45: 315-320.

Miczek KA (1979). A new test for aggression in rats without aversive stimulation: differential effects of $d$-amphetamine and cocaine. Psychopharmacology 60: 253-259.

Miczek KA, Thompson ML, Shuster L (1982). Opioid-like analgesia in defeated mice. Science 215: 1520-1522.

Miczek KA, Covington III H, Nikulina EM, Hammer Jr RP (2004). Aggression and defeat: persistent effects on cocaine selfadministration and gene expression in peptidergic and aminergic mesocorticolimbic circuits. Neurosci Biobehav Rev 27: 787-802.

Min BH, Augustin LB, Felsheim RF, Fuchs JA, Loh HH (1994). Genomic structure analysis of promoter sequence of a mouse mu opioid receptor gene. Proc Natl Acad Sci USA 91: 9081-9085.

Morgan JI, Curran T (1991). Stimulus-transcription coupling in the nervous system: involvement of the inducible proto-oncogenes fos and jun. Annu Rev Neurosci 14: 421-451.

Nikulina EM, Covington III HE, Ganschow L, Hammer Jr RP, Miczek KA (2004). Long-term behavioral and neuronal crosssensitization to amphetamine induced by repeated brief social defeat stress: Fos in the ventral tegmental area and amygdala. Neuroscience 123: 857-865.

Nikulina EM, Hammer Jr RP, Miczek KA, Kream RM (1999). Social defeat stress increases expression of mu-opioid receptor mRNA in rat ventral tegmental area. NeuroReport 10: 3015-3019.

Paxinos G, Watson C (1986). The Rat Brain in Stereotaxic Coordinates. Academic Press: San Diego.

Perugini M, Vezina P (1994). Amphetamine administered to the ventral tegmental area sensitizes rats to the locomotor effects of nucleus accumbens amphetamine. J Pharmacol Exp Ther 270: 690-696.

Robinson TE, Becker JB (1986). Enduring changes in brain and behavior produced by chronic amphetamine administration: a review and evaluation of animal models of amphetamine psychosis. Brain Res 11: 157-198.

Robinson TE, Berridge KC (1993). The neural basis of drug craving - an incentive-sensitization theory of addiction. Brain Res Rev 18: 247-291.

Rodgers RJ, Randall JI (1985). Social conflict analgesia: studies on naloxone antagonism and morphine cross-tolerance in male DBA/2 mice. Pharmacol Biochem Behav 23: 883-887.

Self DW, McClenahan AW, Beitner-Johnson D, Terwilliger RZ, Nestler EJ (1995). Biochemical adaptations in the mesolimbic dopamine system in response to heroin self-administration. Synapse 21: 312-318.
Spanagel R, Herz A, Shippenberg TS (1992). Opposing tonically active endogenous opioid systems modulate the mesolimbic dopaminergic pathway. Proc Natl Acad Sci USA 89: 2046-2050.

Stein EA, Hiller JM, Simon EJ (1992). Effects of stress on opioid receptor binding in the rat central nervous system. Neuroscience 51: 683-690.

Stinus L, Koob GF, Ling N, Bloom FE, Le Moal M (1980). Locomotor activation induced by infusion of endorphins into the ventral tegmental area: evidence for opiate-dopamine interactions. Proc Natl Acad Sci USA 77: 2323-2327.

Tidey JW, Miczek KA (1996). Social defeat stress selectively alters mesocorticolimbic dopamine release: an in vivo microdialysis study. Brain Res 721: 140-149.

Tornatzky W, Miczek KA (1993). Long-term impairment of autonomic circadian rhythms after brief intermittent social stress. Physiol Behav 53: 983-993.

Unterwald EM, Horne-King J, Kreek MJ (1992). Chronic cocaine alters brain mu opioid receptors. Brain Res 584: 314-318.

Van Bockstaele EJ, Pickel VM (1995). GABA-containing neurons in the ventral tegmental area project to the nucleus accumbens in rat brain. Brain Res 682: 215-221.

Vanderschuren LJMJ, Kalivas PW (2000). Alterations in dopaminergic and glutamatergic transmission in the induction and expression of behavioral sensitization: a critical review of preclinical studies. Psychopharmacology 151: 99-120.

Vezina P, Kalivas PW, Stewart J (1987). Sensitization occurs to the locomotor effects of morphine and the specific mu opioid receptor agonist, DAGO, administered repeatedly to the ventral tegmental area but no to the nucleus accumbens. Brain Res 417: $51-58$.

Vivian JA, Miczek KA (1999). Interactions between social stress and morphine in the periaqueductal grey: effects on affective vocal and reflexive pain responses in rats. Psychopharmacology 146: $153-161$.

Watson SJ, Khachaturian H, Coy D, Taylor L, Akil H (1982). Dynorphin is located throughout the CNS and is often colocalized with alpha-neo-endorphin. Life Sci 31: 1773-1776.

Yamamoto M, Komori T, Matsumoto T, Zhang K, Miyahara S, Shizuya K et al (2003). Effects of single and repeated prolonged stress on mu-opioid receptor mRNA expression in rat gross hypothalamic and midbrain homogenates. Brain Res 980: 191-196.

Zeman P, Alexandrova M, Kvetnansky R (1988). Opioid mu and delta and dopamine receptor number changes in rat striatum during stress. Endocrinol Exp 22: 59-66.

Zubieta JK, Gorelick DA, Stauffer R, Ravert HT, Dannals RF, Frost JJ (1996). Increased mu opioid receptor binding detected by PET in cocaine-dependent men is associated with cocaine craving. Nat Med 2: 1225-1229. 